\title{
Estimating Employment Gains of the Proposed Infrastructure Stimulus Plan in Post-Covid-19 South Africa
}

\author{
Alexis Habiyaremye $^{1}\left[\mathbb{D} \cdot\right.$ Olebogeng Molewa $^{1} \cdot$ Pelontle Lekomanyane ${ }^{1}$
}

Accepted: 25 March 2021 / Published online: 16 April 2021

() European Association of Development Research and Training Institutes (EADI) 2021

\begin{abstract}
For the economic recovery in the wake of Covid-19 pandemic, South Africa announced the launch of an ambitious ZAR 2.3 trillion infrastructure investment plan. This paper uses a simplified yet reliable method to analyse the potential growth and employment effects of this stimulus plan. Based on lower and upper bound values of the country's estimated fiscal multipliers, we built a scenario prediction template with which output and employment expansion can be analysed within specified constraints on the fiscal space and the country's economic dynamics. Our estimation model suggests that with a $50 \%$ state participation in the recovery investment, the best case scenario of fiscal stimulation would enable the economy to create 2.23 million jobs over the first 5 years of the stimulus investments (of which 1.74 million would be attributed to the stimulus effect), while the more realistic scenario based of the lower bound value of the fiscal multiplier with only $30 \%$ state participation predicts the creation of 1.67 million additional jobs, of which 1.18 million would be attributable to the stimulus. Our analysis also suggests that investing in the types of infrastructure that shift the production technology could change the long-term growth trajectory, while focusing on employment-intensive investment may only generate temporary effects.
\end{abstract}

Keywords Covid-19 $\cdot$ Fiscal stimulus $\cdot$ Fiscal multipliers $\cdot$ Infrastructure investment $\cdot$ Employment elasticity of output

\section{Résumé}

Pour stimuler la reprise économique à la suite des effets de la pandémie de COVID-19, le gouvernement de l'Afrique du Sud a annoncé le lancement d'un plan ambitieux visant à investir 2.300 milliards de rands (ZAR) dans les infrastructures. Cet article utilise une méthode simplifiée mais bien fiable pour analyser les effets potentiels de ce plan de relance sur la croissance économique et la création d'emploi.

Alexis Habiyaremye

habiyaremye@merit.unu.edu

1 Human Sciences Research Council, Merchant House, 116-118 Buitengracht Street,

Cape Town 8001, South Africa 
Sur base des valeurs limites inférieure et supérieure des multiplicateurs budgétaires estimés pour ce pays, nous avons construit un modèle de prévision de scénario avec lequel l'expansion de la production et de l'emploi peut être analysée dans le cadre de contraintes spécifiques sur l'espace budgétaire et la dynamique économique du pays. Notre modèle d'estimation suggère qu'avec une participation de $50 \%$ de l'État à ce plan d'investissements, le scénario le plus optimiste de stimulation budgétaire permettrait à l'économie de créer 2,23 millions d'emplois au cours des 5 premières années d' investissements (dont 1,74 million seraient attribués à l'effet de relance), tandis que le scénario plus réaliste basé sur la valeur limite inférieure du multiplicateur budgétaire avec seulement $30 \%$ de participation de l'État prédit la création de 1,67 million d'emplois supplémentaires, dont 1,18 million seraient attribuables à la relance. Notre analyse suggère également qu'investir dans les types d'infrastructure qui modifient la technologie de production pourrait modifier la trajectoire de croissance à long terme, tandis que se focaliser sur les investissements à forte intensité d'emploi ne peut générer que des effets temporaires.

\section{Introduction}

Severely affected by the Covid-19 pandemic and the resulting imposition of one of the world's most stringent lockdowns, South Africa has seen its economy come under stress and shed more than three million jobs. Despite the adoption of a ZAR 500 billion fiscal package to stabilise the economy and protect employment, preliminary estimates of the impact of lockdown measures suggest that the economy has shed, worsening an already staggering unemployment rate (Smit 2020; National Income Dynamics Study 2020; National Treasury 2020a; StatSA 2020). The corresponding GDP growth estimations predict a decline of $7.2 \%$ for 2020 , with additional risk of swelling the fiscal deficit to 15.7\% of GDP (Altman 2020; Arndt et al. 2020; Naidoo 2020). Subsequent pressure on the stretched country's resources forced the government to adopt a risk-adjusted phased resumption of economic activities to prevent economic devastation. Even before the outbreak of the current Covid-19, South Africa suffered from a persistently high unemployment rate, currently at more than $30 \%$ (StatsSA 2020).

The stringent lockdown measures imposed since 27 March 2020 to curb the spread of the pandemic produced sizeable disruptive effects on the labour market dynamics. To avoid a disorderly economic implosion as the lockdown froze all nonessential activities, the government announced a ZAR 500 billion fiscal package (approximately $10 \%$ of the 2019 GDP), of which ZAR 100 billion would be targeted at supporting small and medium-sized enterprises (SMEs) for employment creation and preservation (See Table 1). To support the post-Covid-19 recovery, the government announced an ambitious infrastructure stimulus package on June 24, 2020, with projected investments of ZAR 2.3 trillion in the modernisation and expansion of the country's key infrastructure. These investments are expected to generate 1.8 million jobs and render the economy ready for a greener future after the health crisis 
Table 1 South Africa's COVID-19 fiscal stabilisation package

\begin{tabular}{lll}
\hline Target programme & $\begin{array}{l}\text { Amount in ZAR mil- } \\
\text { lion }\end{array}$ & $\begin{array}{l}\text { Amount in } \\
\text { supplementary } \\
\text { budget }\end{array}$ \\
\hline Credit Guarantee Scheme & 200,000 & 200,000 \\
Job creation and support for SME & 100,000 & 6000 \\
Tax measures for income support & 70,000 & 70,000 \\
Support to vulnerable households for 6 months & 50,000 & 41,000 \\
Wage protection & 40,000 & 22,000 \\
Health services & 20,000 & 14,000 \\
Other frontline services & & 20,000 \\
Support to municipalities & 20,000 & 13,000 \\
Basic and higher education & & 20,000 \\
Provisional allocation for covid-19 relief package & & 11,000 \\
Other & & 455,000 \\
Total & 500,000 & \\
\hline
\end{tabular}

Source National Treasury (2020a)

The initially proposed stimulus package of ZAR 500 billion represents $10 \%$ of the country 2019 GDP and the amount in the supplementary budget represents the adjusted expenditure on the stimulus, whereby some of the initially planned spending could not take place due to various administrative constraints

is brought under control (Sguazzin 2020). ${ }^{1}$ This infrastructure stimulus is part of broader macroeconomic policy measures intended to accelerate growth and create employment during the recovery period to ensure that the economy is made more resilient against future exogenous shocks.

How do macroeconomic policy measures taken by governments and central banks in the form of fiscal stimulus and monetary expansion translate into mitigating crises and enhancing economic performance? How does the temporary effects of fiscal stimulation translate into job creation? Fiscal multipliers are useful tools to analyse the effects of exogenous fiscal shocks on output expansion of (Blanchard and Perotti 2002; Auerbach and Gorodnichenko 2012; Spilimbergo et al. 2009; Sinai 2009; Jooste et al. 2013). Having a reliable estimate of the fiscal multipliers can help inform policy decisions, while an underestimation of the economy's multipliers can lead to miscalculations and delays in fiscal interventions (Batini et al. 2014a). An overestimation, for its part, may lead to hasty fiscal expenditures decisions whose benefits could fail to materialise. In this paper, we apply the fiscal multiplier estimation method proposed by Batini et al. (2014a) to the South African case and explore how different scenarios of investment in infrastructure could affect the recovery path

\footnotetext{
1 Given the precarious state of the public finances stretched by Covid-19-related expenditures and a large loss of tax revenue, the infrastructure investment plan will require public-private partnerships to finance its implementation.
} 
and give an upward push to the post-Covid-19 growth and employment. ${ }^{2}$ Because the pre-Covid South African economy was already locked in an unfavourable predicament of middle-income growth trap (Makgetla 2013; Bhorat et al. 2014; Doner and Schneider 2016; Luiz 2016; Kruss 2021), the study will also explore the role of the shift from profit-led to wage-led growth regime, as well as other structural reforms in unlocking the structural growth trap and catalysing recovery.

The rationale for using infrastructure investments to support recovery in times of recession finds its roots in both economic modelling and empirical studies examining output response to fiscal policy change. Aggregate demand stimulation through massive investments in infrastructure financed through an increase in budget expenditure has been shown to have higher fiscal multipliers than other forms of fiscal policies in most economies affected by crises (Sinai 2009; Spilimbergo et al. 2009; Verick and Islam 2010; Auerbach and Gorodnichenko 2012). Investment in infrastructure is thought to have growth stimulating advantages because of its durability and the persistence of its multiplier. ${ }^{3}$ Literature on fiscal policy impact also points to stronger effectiveness of fiscal stimulus during periods of economic downturn than during expansions (see Auerbach and Gorodnichenko 2012; Baum et al. 2012 among others). In the context of the current recession, the growth-enhancing benefits of fiscal stimulus are therefore more likely to be optimised when the corresponding funds are used for investments rather than public consumption or tax cuts (Verick and Islam 2010; Batini et al. 2014a).

South African infrastructure assets are considered quite developed, especially when compared to the infrastructure endowments of the country's neighbours. With a total of 755,000 km of roads, of which 158,124 km are paved and in good maintenance conditions, the country's road network is among the 10 best in the world (CIA 2020). A closer look reveals important bottlenecks in the quality and the functioning of the existing infrastructure services, however. The 2019 DBSA report on infrastructure indicates that South African infrastructure is poorly maintained and not adequately meeting the growing demand (Financial Mail). In its 2017 Infrastructure Report Card, the South African Institute of Civil Engineering warned that the South African infrastructure was at risk of failure (overall grading: D+). Despite the sustained efforts to invest in infrastructure expansion with the view to broaden access to previously excluded communities, the maintenance of ageing infrastructure assets has been lacking, to the extent that the ageing of the water distribution infrastructure is considered to pose a threat to the future reliability of water supply (Ntjatsane 2017). Power generation infrastructure has also shown considerable bottlenecks, to the extent that load shedding has become a regular phenomenon since 2007. Low capacity and limited technical skills in the public sectors have been identified as the main constraints to the growth and maintenance of existing infrastructure assets.

\footnotetext{
${ }^{2}$ Until the virus is vanquished, however, there cannot be a return to the normal conditions enabling fiscal stimulus to expand output (Krueger 2020). Planning for the post-Covid-19 recovery is therefore premised on the assumption that economic activities will resume at a reasonable capacity if appropriate precautionary measures are taken to keep infection rate under control.

${ }^{3}$ According to Ramey (2020), empirical evidence for this advantage is scant and delays in project implementations are considered to have adverse effects on the magnitude of the fiscal multiplier.
} 
Water and sanitation infrastructure is of special concern, since the country has ZAR 898 billion in investment and maintenance arrears according to the 2018 National Water and sanitation master plan (Financial Mail 2019). Because of the rapid growth of vehicle registration in the country, road and public transport infrastructure assets are also under pressure and require an annual investment of ZAR 138 billion to keep them in good maintenance conditions (Business Tech 2019). Due to competition for government funding in development projects, finding the financial resources to keep roads in good maintenance conditions is a recurrent challenge for government budgeting processing (Van Rensburg and Krygsman 2019). In the post-Covid era, digital infrastructure will play an increased role in new production methods. The country's digital infrastructure system will therefore require sustained investment to expand beyond its current reach while addressing the price distortions that have rendered it one of the most expensive in the world (see, e.g. Ahmad 2020; Isa 2019; National Planning Commission n.d.).

For the current analysis, it is important to underscore that the compromise between health protection and the reopening of the economy means that capacity utilisation will remain suboptimal until the health risk has been completely eliminated, at which time the necessary structural reforms would need to be put in place for the additional macroeconomic measures to contribute to a new capacity expansion.

The paper is outlined as follows: the next section provides a brief overview of the socioeconomic and fiscal context of South Africa at the inception of the Covid-19 pandemic and presents existing estimates of the impact of the crisis on growth and employment. Section three presents the determinants of fiscal multipliers and the estimation method used to determine its value for South Africa. Thereafter, the estimated multiplier is used to examine how the various investment scenarios may affect the recovery growth and thereby the employment opportunities. Section five discusses the implications of the intended fiscal stimulus for employment and income distribution. The final section provides concluding remarks and highlights the limitations of the study.

\section{Estimating Fiscal Multipliers for South Africa}

\section{Fiscal Multipliers and Their Determinants}

Under a neoclassical economics approach, it is argued that an increase in deficitfinanced government spending will not affect consumers' intertemporal budget constraint and therefore will not affect aggregate demand because future taxes will prompt forward looking households who face the Ricardian equivalence to increase current savings in budget allocation between current and future consumption (Barro 1974; Goodfriend and King 1997; Jooste et al. 2013). In New Keynesian models, in contrast, monopolistic competition and costly price adjustments result in sticky prices in the short run and open the possibility for fiscal and monetary policy to stimulate aggregate demand (Rothenberg and Woodford 1992; Smets and Wouters 2007; Gali et al. 2007). Fiscal multipliers are therefore the output response to changes in fiscal and monetary policy under the assumption of sticky prices in the 
short run. It is useful to underscore the importance of fiscal targeting because of the role played in the transmission mechanism of aggregate demand stimulation by the marginal propensity to consume (MPC) of those who received additional income. For the fiscal measures to be effective, the marginal propensity to consume must be large: the measures should therefore be targeted in priority toward liquidity constrained consumers.

The size of the fiscal multiplier depends on the specific country, varies in time and is affected by the circumstances under which the stimulus impulse is given. The reliability of fiscal multiplier estimates is, however, challenged by methodological difficulties associated with their estimation. The main empirical challenge in the estimation of the multiplier is the simultaneity bias, which may occur, for example, when the increased government spending (or tax cut) comes in response to a negative shock on output. In that case, where output change triggered the stimulus to generate additional output, the stimulus can no longer be considered as strictly exogenous and the estimation of the multiplier effects may need to use structural equation models to account for reverse causality.

Insights from various models of output response to fiscal policy shocks have suggested that output multipliers are generally higher in the following conditions:

- in times of downturn (Auerbach and Gorodnichenko 2012; Batini et al. 2014a);

- when the output gap is large (Spilimbergo et al. 2009; Makrelov et al. 2018a, b) ${ }^{4}$;

- when government uses deficit finance rather than taxation to finance it (Akanbi 2013; Abiad et al. 2015; US Congressional Budget office 2016; Makrelov et al. 2018a, b, Kemp and Hollander 2020)

- when expansionary monetary policy is simultaneously implemented to keep interest rates from rising (Hall 2009; Christiano et al. 2011, Eggerston et al. 2011; Auerbach and Gorodnichenko 2012, Makrelov et al. 2018a, b; Kemp and Hollander, 2020) ${ }^{6}$;

- when it directs the spending into government investment rather than consumption (Spilimbergo et al. 2009; Verick and Islam 2010; Auerbach and Gorodnichenko 2012; Mabugu et al. 2013, Batini et al. 2014a).

Verick and Islam (2010) compared the fiscal multipliers of different component of fiscal packages calculated in different studies and suggested that when governments prepare to enact fiscal stimulus packages, they should concentrate on spending measures rather than tax cuts. Among government spending options, infrastructure investment presents long-term advantages for multiplier maximisation (Verick and Islam, 2010, Mabugu et al., 2013; Yulek et al. 2018; Ramey 2020).

\footnotetext{
${ }^{4}$ Output gap is defined as the difference between actual and potential output. Potential output is the level of output that would prevail under flexible prices and wages in the absence of the price and wage markup shocks (Taylor 1993).

${ }^{5}$ Deficit financed multiplier are high when there is no concern of debt sustainability (Reinhart et al. 2012; Ilzetzki et al. 2013).

${ }^{6}$ The lowering of interest rate acts as an accelerator of fiscal multipliers (Hall 2009; Christiano et al. 2011; Eggertsson et al. 2011; Kemp and Hollander 2020).
} 


\section{Estimation Methods}

Estimating fiscal multipliers requires an in-depth understanding of the working of aggregate demand, monetary policy reaction and the role of investment in supportive infrastructure. Various methods for the estimation of the magnitude of output response to fiscal changes exist, each of which has strengths and weaknesses depending on methodology and data availability. Two main categories of estimation methods are used: empirical estimation using structural vector autoregression (SVAR) analysis based on historical data of the country in question and dynamic stochastic general equilibrium (DSGE) modelling. The values of the estimated fiscal multipliers are affected by the technique used to compute them. While DSGE models present the advantage of synthesising the interactions and combination of many microeconomic decisions influencing the behaviour of the economy as a whole, they have the drawback of rigidity that may fail to capture the non-linearity in multiplier behaviour. ${ }^{7}$ They also require access to sophisticated disaggregation of spending and output data with respect to the various components of the GDP. SVAR estimations for their part, must rely on the availability of long time series data, which are often not available for many emerging economies and low-income countries (Spilimbergo et al. 2009; Batini et al. 2014a). ${ }^{8}$

Because of the particularity of the Covid-19 crisis, in which the usual dynamics in the economy have been disrupted, we make use of the alternative methodological approach proposed by Batini et al. (2014a) to circumvent lack of access to detailed and high-frequency data, while keeping a reasonable reliability of the calculated multiplier.

\section{Estimation with the "Bucket" Method}

For the formal estimation of the multiplier as proposed by Batini et al. (2014b), the determinants are classified under two types: structural country characteristics and conjunctural factor that can make multipliers deviate from habitual levels. Structural characteristicsm comprise the followings:

- Trade openness: high propensity to import constitutes a "leakage" as it diverts (part of) aggregate demand stimulation to foreign-produced goods and services (Spilimbergo et al. 2009; Ilzetzki et al. 2013);

- Labour market rigidity: higher rigidity by strong unions ensures wage and price stickiness: higher multipliers (Gorodnichenko et al. 2012);

\footnotetext{
7 Model-based multiplier is also heavily dependent on the specific characteristics of the model and the calibration chosen by their authors (Batini et al. 2014a).

8 As pointed out by Boussard et al (2013), the VAR estimation techniques are mostly used for temporary fiscal shocks, whereas model-based estimation, such as the DSGE-based estimation, can accommodate temporary shocks as well as permanent fiscal measures. The current study deals with temporary fiscal shocks.
} 
- Size of automatic stabilisers: larger automatic stabilisers dampen the effect of fiscal measures (Dolls et al. 2012);

- Exchange rate regime: flexible exchange rate regimes lead to smaller multiplier because movement in exchange rate can offset the impact of fiscal policy measures (Ilzetzki et al. 2013; Makrelov et al. 2018a, b);

- Government debt level: high debt-to-GDP ratio leads of smaller multiplier because of the negative effects of debt sustainability concerns (Ilzetzki et al. 2013);

- Public expenditure management/and revenue administration: inefficiencies in expenditure management and tax collection lead to lower multipliers.

Conjunctural factors tend to increase multipliers above their normal level:

- Business cycle phase: multipliers increase in recessions and shrink in expansions.

- Accommodative monetary policy: expansionary monetary policy amplifies aggregate demand stimulation by restraining interest rates: multipliers are much higher at the zero lower bound interest rate.

This method is applied in three steps: in the first step, a score is assigned to the economy according to the number of categories in which each of its six structural factors is classified as high or low multiplier. The value of 1 if the characteristic of that component corresponds to a high multiplier, zero otherwise. Although the model benchmarks are based on studies covering advanced economies, guidance for reasonable adaptations for emerging economies is provided in Batini et al. (2014a). As benchmarks, strong labour unions can be used as an indicator of labour market rigidity, natural stabilisers are considered weak when the ratio of public expenditure to GDP is below $40 \%$, while a government debt-to-GDP ratio of $40 \%$ is considered a benchmark for "safe" in emerging market economies. A fixed exchange regime gives a high multiplier score while an average ratio of import to GDP of the last five years gives a score of 1 if it is below 30\%, zero if it is above. The total score determines the classification of the corresponding country in one of the multiplier level "buckets": low (0-3), medium (3-4) or high (4-6). All structural characteristics are given an equal weight because of lack of sufficient empirical evidence to distinguish the relative importance of each factor in determining the level of the multiplier.

Table 2 Structural characteristic scores and fiscal multiplier ranges

\begin{tabular}{ll}
\hline Country bucket category based on scores & $\begin{array}{l}\text { Fiscal } \\
\text { multiplier } \\
\text { range }\end{array}$ \\
\hline Low multiplier & $0.1-0.3$ \\
Medium multiplier & $0.4-0.6$ \\
High multiplier & $0.7-1.0$ \\
\hline
\end{tabular}

Source Batini et al. (2014a) 
In the second step, these scores are translated into normal time multiplier estimates, according to the suggested conversion table as follows (Table 2):

In the third step, the conjunctural characteristics are used to adjust the estimate by scaling up or down the multiplier ranges depending on the potential output gap: both the lower and the upper range are increased by $60 \%$ for a large negative output gap and decreased by $40 \%$ if the output gap is at its positive maximum. A further $30 \%$ adjustment of the multiplier range is added for the monetary policy lower bound constraint: the adjustment factor can be interpolated between 0 and $30 \%$ to reflect the effectiveness of the monetary policy to support the fiscal stimulation.

These adjustments are done in a multiplicative way:

$$
M=M_{\mathrm{NT}} *(1+\text { Cycle adjustment }) *(1+\text { Monetary adjustment }),
$$

where $M$ is the final estimate of the multiplier and $M_{\mathrm{NT}}$ is the estimated normal time multiplier based only on structural characteristics.

The obtained multipliers are estimates for the first year of the fiscal policy measure.

\section{Scores for South Africa}

A score of 1 was given for trade openness: the average import to GDP ratio is just below 30\% and the rate was 29.35\% in 2019 according to the World Bank data. For the exchange rate regime, the country receives a score of zero, because the currency is heavily traded under a flexible exchange rate. A score of 1 was given for labour market rigidity because of the well-known strength of the labour unions and their alliance with the ruling party. For automatic stabilisers, a score of 1 is given because the average government expenditure to GDP ratio is below the benchmark of $40 \%$.

For government debt-to-GDP ratio, gross government debt was estimated to increase from ZAR 3.18 trillion (61.6\% of GDP) in 2019/20 to ZAR 4.38 trrillion (71.6\% of GDP) in 2022/23, of which foreign debt accounts for $9.6 \%$ on average. The projected borrowing requirement for 2020/21 was ZAR 432.7 billion before the additional requirements in response to the pandemic are introduced (National Treasury 2020b). The already-mentioned downgrading of the country's sovereign debt and the heavy interest payment burden in the national budget means that South Africa has a score of zero on that measure (Fig. 1). It can be argued that the additional borrowing from IMF and New Development Bank to help finance the ZAR 500 billion Covid-19 stabilisation package pushed the country further into a narrow fiscal space. As for the effectiveness of public expenditure management, numerous incidents of ineffective, inefficient and corrupt public procurements that have led to the establishment of the inquiry commission into state capture and cast sufficient doubt on the effectiveness to make a score of 1 difficult to justify. ${ }^{9}$

\footnotetext{
9 We wish to emphasise that this is not pre-judging the outcome of the inquiry or the authenticity of the allegations. The score is put to zero by default because the very existence of serious mismanagement allegations makes it difficult to give a score of 1 , irrespective of their adjudication.
} 

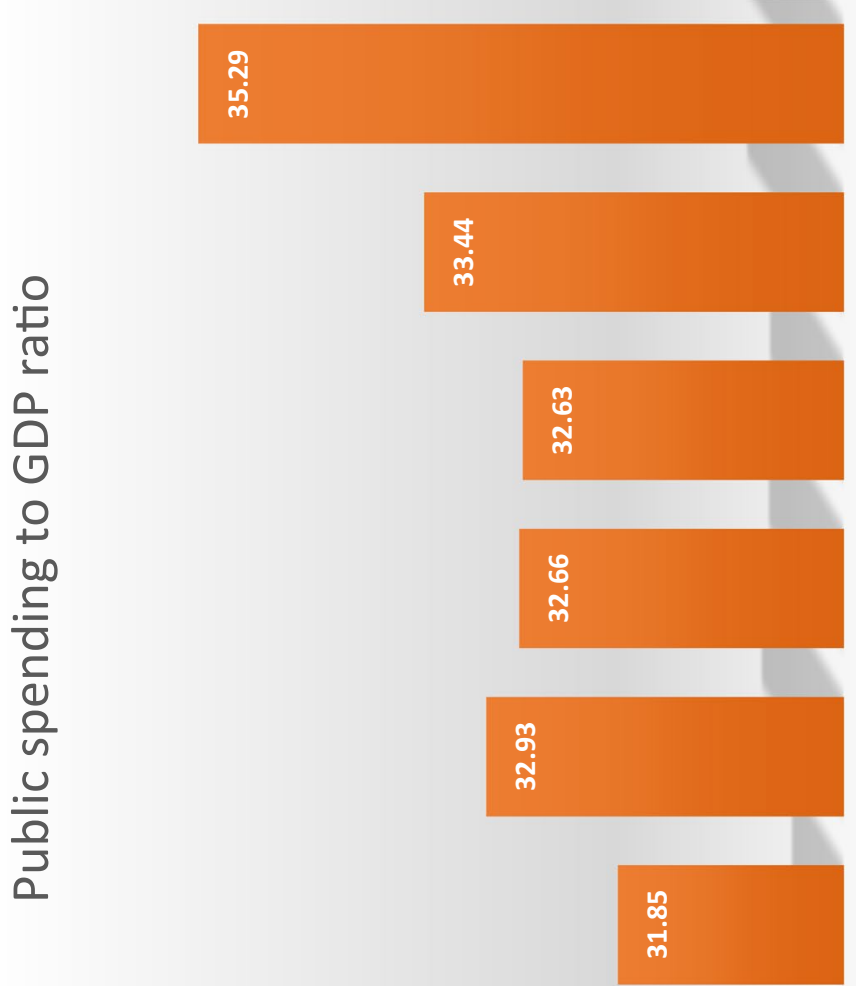

궁

مه

음

व

은

$\frac{.}{ㅇ ㅡ ㅁ ~}$

0

ㄱำ

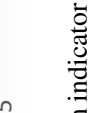

สิ

$\stackrel{9}{7}$

กิ 
Table 3 Structural characteristics scores for South Africa

\begin{tabular}{ll}
\hline Structural characteristic & Score \\
\hline Trade openness & 1 \\
Labour market rigidity & 1 \\
Exchange rate regime & 0 \\
Size of automatic stabilisers & 1 \\
Public debt level & 0 \\
Effectiveness of expenditure management & 0 \\
Total score & 3 \\
\hline
\end{tabular}

This score produces a total score of 3 points, which puts South Africa in the lower or medium range for multipliers (because of the overlap of ranges) as displayed in Table 3. For the most optimistic scenario of recovery, we could thus categorise the country in the medium bucket (it should alternatively be classified in the lower range for a conservative estimate). The adjustment for the conjunctural factors considers that the country is experiencing a very sharp decline in output with an estimated GDP drop of more than $7 \%$. This gives support for the suggested $60 \%$ adjustment for the lower and the upper bound.

The South African Reserve Bank (SARB) has responded to the crisis by gradually lowering the repo rate with a total of 300 basis points from 6.5 to $3.5 \%$. Even though this is not the zero interest lower bound (ZLB), it is commonly understood from the pronouncements of the monetary policy committee that the rate will not go further down anytime soon. Our interpolation gives an adjustment of $15 \%$ for the accommodative monetary policy. This gives a final multiplier ranging between 0.736 and 1.104 .

This estimate compares reasonably with earlier results in studies using DSGE and structural VAR models (Table 4). ${ }^{10}$

\section{South Africa's Post-Covid-19 Recovery Pathways Under the Proposed Infrastructure Stimulus}

\section{Estimation Template and Baseline Assumptions}

Both theory and empirical estimates suggests that public capital spending, especially infrastructure investments, have had significant positive effects on long-run output and productivity growth (Fedderke and Bogetic 2009; Gallen and Winston 2019;

\footnotetext{
10 As Table 4 shows, there is a varied literature on fiscal multipliers in South Africa with estimations presenting different degrees of strength depending on the data available to authors. Estimations based on historical data may, however, be inadequate to assess the potential behaviour of the current Covid-19 crisis. The bucket method enables an estimation based on the most recent data available and may thus present the advantage of being anchored in the current reality.
} 


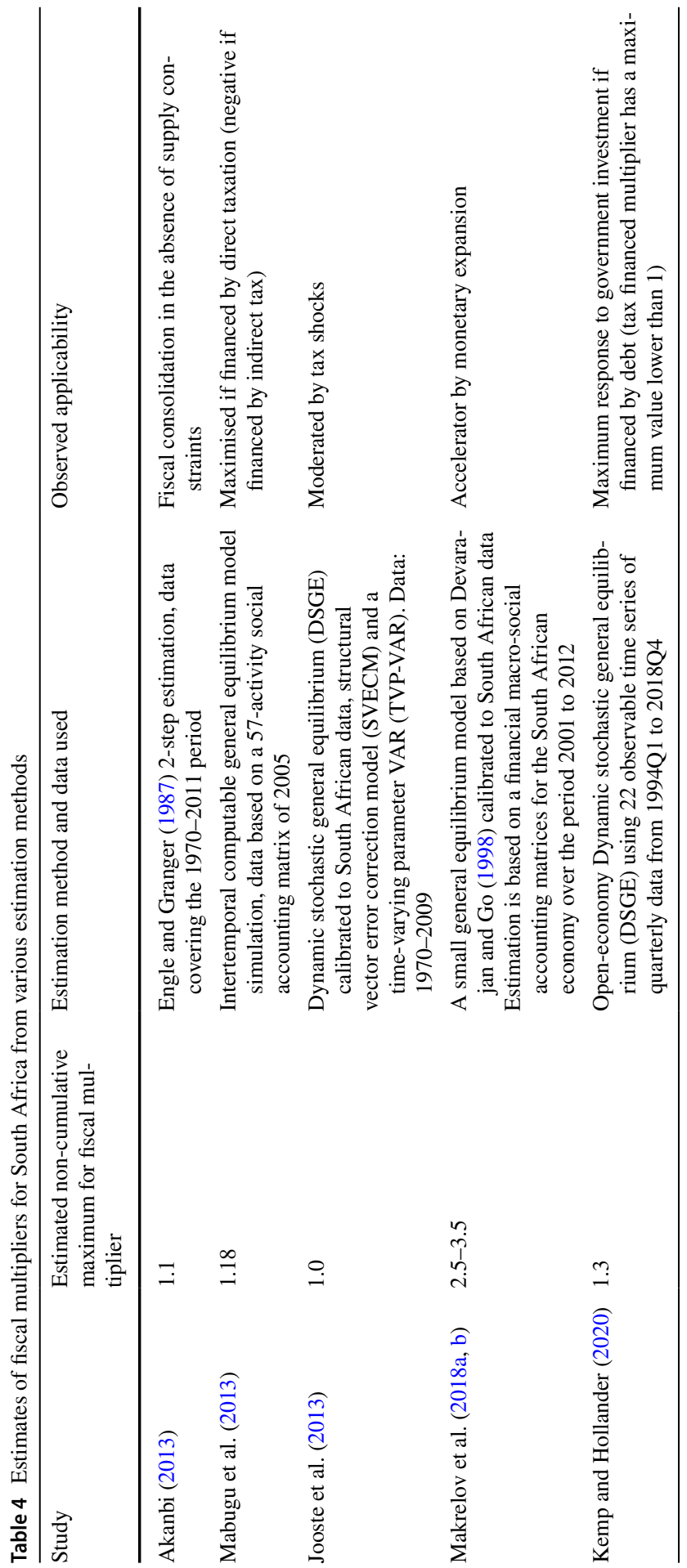


Ramey 2020). ${ }^{11}$ The beneficial effects of infrastructure on growth are achieved through two main transmission channels: increase in government spending raises the stock of productive public capital which contributes to increasing long-run total factor productivity (TFP) (Aschauer 1989; Baxter and King 1993), while the spending itself contribute to increasing aggregate demand in the contemporaneous period under neo-Keynesian sticky prices and wages. ${ }^{12}$ For the purpose of making a reliable estimation of the effects of the proposed infrastructure stimulus package, a keen understanding of the magnitude and persistence of fiscal multipliers is key to a sound analysis of the potential impact of fiscal policy change on output expansion over a horizon of more than 1 year (Batini et al. 2014a). Multiplier estimations based on dynamic models and econometric analysis have generally suggested that the effect of an exogenous fiscal shock on output tends to decline and revert to zero within five years, even when fiscal measures are permanent (Batini et al. 2012; Baum et al. 2012; Coenen et al. 2012). The maximum impact is usually reached in the second year where the multiplier is on average 10-30\% higher than in the first year (Mineshima et al. 2014).

In order to estimate how the fiscal stimulus of infrastructure spending may influence growth in the recovery period, we use the computed fiscal multipliers and fiscal shock forecast templates that show how alternative multiplier values translate to various growth trajectories. This simple approach, based on fiscal multipliers, is a useful alternative method to estimate the output effect of fiscal shocks and presents some advantages in comparison to more sophisticated macroeconomic model-based methods: in addition to being easy to implement, it can control for different shocks, adjust to country-specific factors, and allow for changes of the composition of the stimulus over time (Batini et al. 2014a; Bi et al. 2013). It also accommodates the circular relations between output and fiscal variables, therefore enabling the effect of the fiscal shock to adjust to changes in variables linked through that circularity. Finally, this flexible analysis method helps circumvent the data limitation problem and enables various sensitivity analyses to be run in order to ensure the robustness of our estimates in the face of uncertainty of some of the parameters.

To allow for enough flexibility, we make projections for the next 10 years as recommended by Batini et al. (2014a). The baseline scenario is a projection based on National Treasury GDP forecast included in the 2020 budget review, which was adjusted for the estimated 7.2\% drop in output for the current year (2020). ${ }^{13}$ Beyond the 2022 horizon of projected values, our baseline values projected by the templates are based on the assumption of maintaining the same ratio of tax revenue to GDP,

\footnotetext{
11 The purported causality between infrastructure investment and productivity is, however, not unchallenged, both on methodology and on the direction of causality (Calderón and Servén 2004; Gramlich 1994; Ramey 2020).

12 Different types of infrastructure may have different effects on productivity growth: Fedderke and Bogetic (2009) found railways to have higher elasticities on TFP than other types of infrastructure for South Africa.

13 In a report released on 8 September 2020, Stats SA indicated that GDP fell by more than 16 percent between the first and second quarters of 2020. The baseline scenario takes this fall in output into account but excludes policy changes, in line with Batini (2014a).
} 
which was stable at $26.3 \%$ until the pandemic. Government expenditures are also assumed to remain within a bound around $32 \%$ of the GDP over the prediction period, while inflation is assumed to keep its trend of the last five years. Monetary policy adjusts interest rates according to Taylor's rule. The average interest charge on government debt was $15.2 \%$ in the years before the pandemic (National Treasury 2020c). As the South African Reserve Bank lowered the key interest rate with 300 basis points to respond to the Covid-19 crisis, our baseline assumptions are based on lowering future borrowing rates by the same 300 basis points. Public capital expenditure to GDP ratio is also assumed to be a continuation of its past value and trend, while the ZAR 145 billion extra costs for Covid-19 containment and economic stabilisation is considered a once-off spending, therefore not part of recurring expenditures. Output is assumed to respond to the full reopening of the production after the infection has been brought under reasonable control levels, operating at $90 \%$ of the pre-Covid capacity in 2021 because of the limitations imposed by prevention measures, but returning to full capacity in 2022, the year that the economy becomes fully operational (starting from a smaller basis and compensating for the sudden drop of this year). The rates then levels off after the second year and return to a moderate $2.5 \%$. The ZAR 91.5 billion borrowed from multilateral banks at concessional interest rates $1.1 \%$ is assumed to be repaid at the end of the five-year period as announced. The baseline scenario excludes the infrastructure spending whereas the considered stimulus growth scenarios take the infrastructure spending as the fiscal shock.

For the 10-year forecast period, we take into account the effects of multiplier persistence and the cumulative effects of successive shocks when investments are made each year. For simplification, we assume that the proposed total package of ZAR 2.3 trillion will be invested over ten years in equal amounts each year whereby the government partners with the private sector for financing according to the historical proportion of government share of capital accumulation spending. Different ratios can be introduced for sensitivity analysis.

\section{Realistic and Best Case Scenarios}

In this study, we consider four scenarios towards a growth trajectory, two of which are based on the lower bound value of the middle-bucket multiplier (realistic scenarios), and two of which are based on the higher bound value of the multiplier (best case scenarios).

The realistic scenario uses the lower bound multiplier value and computes the GDP trajectory by adding the estimated additional output generated through the multiplier effect as a result of the fiscal injection and the corresponding aggregate demand expansion under sticky prices and wages. The persistence of the multiplier effect is calibrated to increase to $20 \%$ above its first-year value, then gradually decline to less than 20 of its initial value as the output gap shrinks and dissipates after the fifth year (see Batini et al. 2014a; Bi et al. 2013). ${ }^{14}$ The proposed

$\overline{14} \mathrm{Bi}$ et al. (2013) consider that the multiplier persists over seven years with the hysteresis effect. 
Table 5 Cumulative effect of infrastructure investment shocks lower bound multiplier

$\begin{array}{llllllllll}\text { Effect on } & 2021 & 2022 & 2023 & 2024 & 2025 & 2026 & 2027 & 2028 & 2029\end{array}$

year $>>$

\begin{tabular}{lllllllllll} 
Impulse year & & & & & & & & & & \\
2021 & 0.68 & 0.75 & 0.60 & 0.24 & 0.05 & & & & \\
2022 & & 0.68 & 0.75 & 0.60 & 0.24 & 0.05 & & & \\
2023 & & & 0.68 & 0.75 & 0.60 & 0.24 & 0.05 & & \\
2024 & & & & 0.68 & 0.75 & 0.60 & 0.24 & 0.05 & \\
2025 & & & & & 0.68 & 0.75 & 0.60 & 0.24 & 0.05 \\
Total & 0.68 & 1.43 & 2.03 & 2.27 & 2.31 & 2.31 & 1.63 & 0.89 & 0.29 \\
\hline
\end{tabular}

investments are assumed to generate cumulative output stimulation only in the first five years; thereafter, price and wage adjustments are presumed to have absorbed the effect, since the investment programme will also be anticipated. The debt is assumed to mature over 10 years while government only pays interest charges over the considered period. The currency's exchange rate is assumed to remain stable and no additional exogenous shocks are modelled.

The template scenario construction takes into account the overlapping effects of fiscal shocks introduced in different years, given the persistence of multiplier effects. As a result, the projected GDP in the second year incorporates the first-year effect of the fiscal injection in that year, as well as the second-year effect of the begin-year injection. Likewise, the third-year GDP projection is based on the first-year multiplier of the third-year fiscal stimulus, second-year multiplier of the second-year stimulus, as well as the third-year multiplier of the begin-year stimulus, as indicated in Table 5.

The proposed ZAR 2.3 trillion stimulus investment (equivalent to USD133 billion) is aimed to run over ten year for the purpose to create a total of 1.8 million additional jobs (Sguazzin 2020). The plan unveiled by President Ramaphosa includes the followings:

- 71 housing projects with a projected investment value of ZAR1400 billion for 370,000 jobs;

- 25 energy projects with ZAR 270 billion in investment to support 260,000 jobs;

- 33 agriculture projects worth ZAR 28.5 billion with the potential to create 93,300 jobs;

- 65 transport projects worth ZAR 294 billion rand that could support 298,000 jobs;

- 42 water and sanitation projects, with a projected investment value of ZAR170 billion that could create 96,000 jobs;

- Seven digital infrastructure projects with a total value of ZAR 107 billion with a potential to support 707,000 jobs.

To see how this investment programme might impact the economy, we simulate a realistic scenario in which the government partners with the private sector to 
raise the necessary funds, where private sector partners raise $70 \%$ of the required investment to avoid an unsustainable increase of the government debt-to-GDP ratio. Assuming for simplification that the investments are spread evenly over the 10-year investment period, ZAR 230 billion is raised each year for infrastructure investment, of which ZAR 69 billion is funded by government borrowing. For the investment to provide the necessary stimulus, the government must also pay for all other planned expenditures and abstain from increasing the taxation rate over the entire stimulus period. ${ }^{15}$

The simulation of this scenario under the assumption of the lower bound value of the fiscal multiplier produces a growth trajectory that climbs to $4 \%$ in the first year, then hovers slightly above $5 \%$ from year 2 to year 5 of the stimulus period before gradually declining to reach $2.5 \%$ in the tenth year. The deficit increases to almost $9 \%$ in the third year as the expenditures grow more rapidly than tax collection, but reverts to the $6 \%$ level in fourth year, even though it gradually increases thereafter as the growth rate declines (Fig. 2).

The related borrowing to finance the investment adds to the government debt but the corresponding amount is not added to the fiscal deficit, since the investment is used to build matching state assets in the form of infrastructure. ${ }^{16}$ Government debt would gradually increase to $100 \%$ of GDP in year 7 of the stimulus and would climb above $110 \%$ in year 9 . The corresponding interest charges would be more than two times the current interest charges on government debt even if the interest rate were kept at the moderate $8.2 \%$ (Fig. 3, right-hand scale). If the yield is allowed to vary with the higher ratio of government debt-to-GDP ratio, the interest charges would climb even higher, which in turn would considerably reduce the ability to repay the principal.

If the upper bound value of the multiplier is used, instead of the lower bound, the growth rate climbs to $6.7 \%$ in the second year and reaches a peak of almost $7 \%$ in the fourth year before declining back to its pre-stimulus trajectory (Fig. 4). The fiscal deficit remains stable around 6\% of GDP and the government debt grows less rapidly because the higher growth generates more tax receipts to pay for the increased interest charges as well as the other planned expenditures. Starting from a level comparable to current situation in South Africa, the ratio of debt to GDP would only reach $90 \%$ in year 8 of the stimulus period and remain below $100 \%$ until the year 10 from the beginning of the stimulus (Fig. 5). The sustainability of South Africa's government debt is an important issue when analysing its stimulus investment capacity because debt-service costs have been the fastest-growing area of spending, rising from $9.8 \%$ of main budget revenue in $2010 / 11$ to $15.2 \%$ in $2019 / 20$ (National Treasury South Africa 2020b).

The primary budget balance, defined as the budget balance net of interest payments, is a key determinant of government debt dynamics. In order to stabilise and

\footnotetext{
15 As recalled by Ramey (2020), introducing distortionary taxes to pay for the stimulus expenditures can reduce the multiplier considerably.

16 The deficit ratio is based on government revenues and expenditures and does not include money borrowed by government to finance investment.
} 
Table 6 Projected primary balance at the start of the Covid-19 pandemic

\begin{tabular}{lllll}
\hline Fiscal year & $2019 / 20$ & $2020 / 21$ & $2021 / 22$ & $2022 / 23$ \\
\hline GDP (in ZAR billion) & 5058.40 & 5359.30 & 5676.40 & 6035.10 \\
Allocated expenditures (in ZAR bn) & 1539.50 & 1536.72 & 1592.19 & 1650.80 \\
Govt revenues (in ZAR bn) & 1516.99 & 1583.91 & 1682.84 & 1791.32 \\
Prim balance & 0.00 & 0.01 & 0.02 & 0.02 \\
Debt service (in ZAR bn) & 205.00 & 229.30 & 258.50 & 290.10 \\
Budget deficit & 6.3 & 6.8 & 6.2 & 5.7 \\
\hline
\end{tabular}

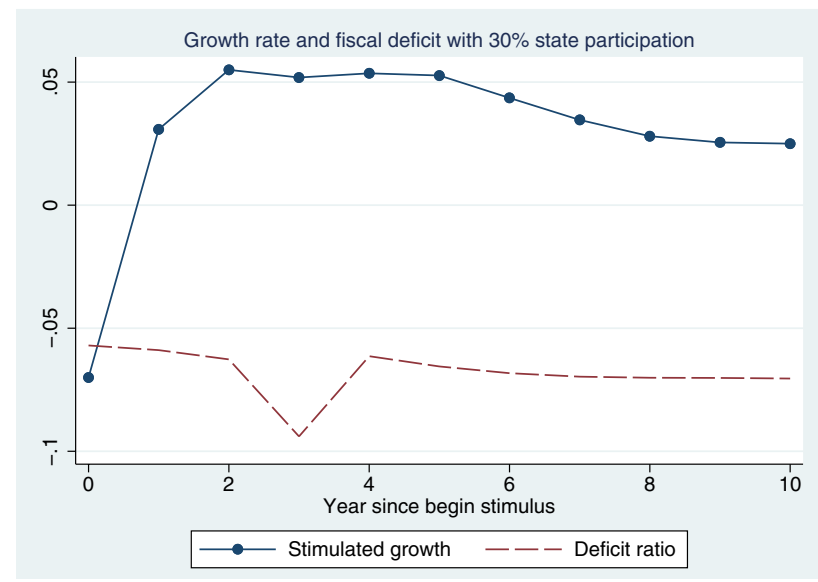

Fig. 2 Stimulated growth rate and deficit if 30\% state participation (lower multiplier)

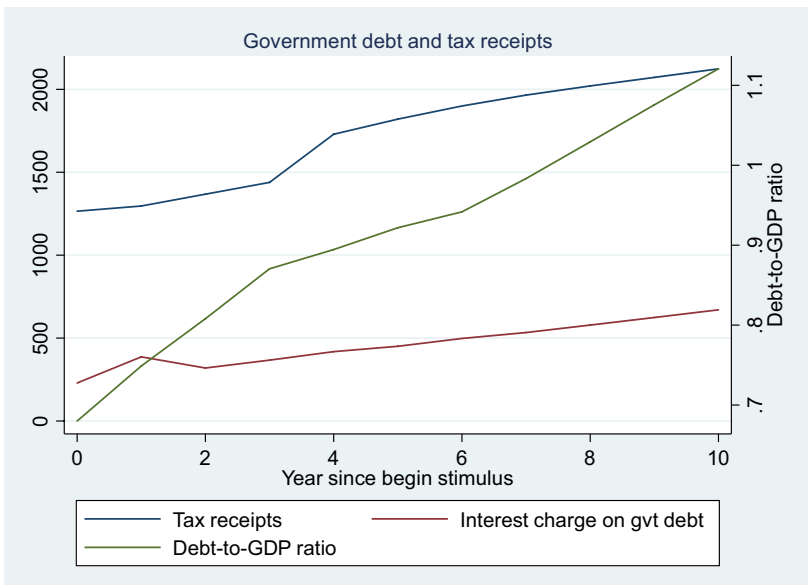

Fig. 3 Debt and interest charges if 30\% state participation (lower bound multiplier)

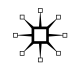




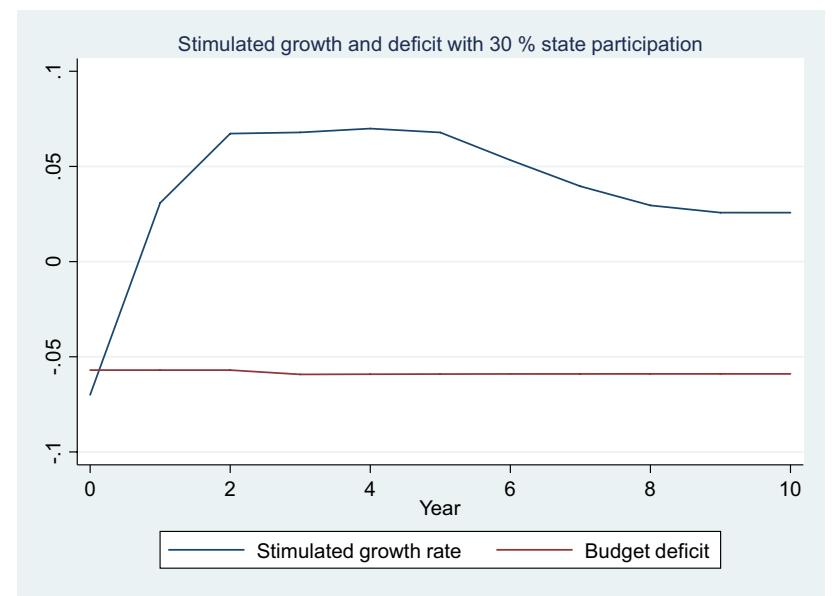

Fig. 4 Growth and deficit if 30\% state participation (upper bound multiplier)

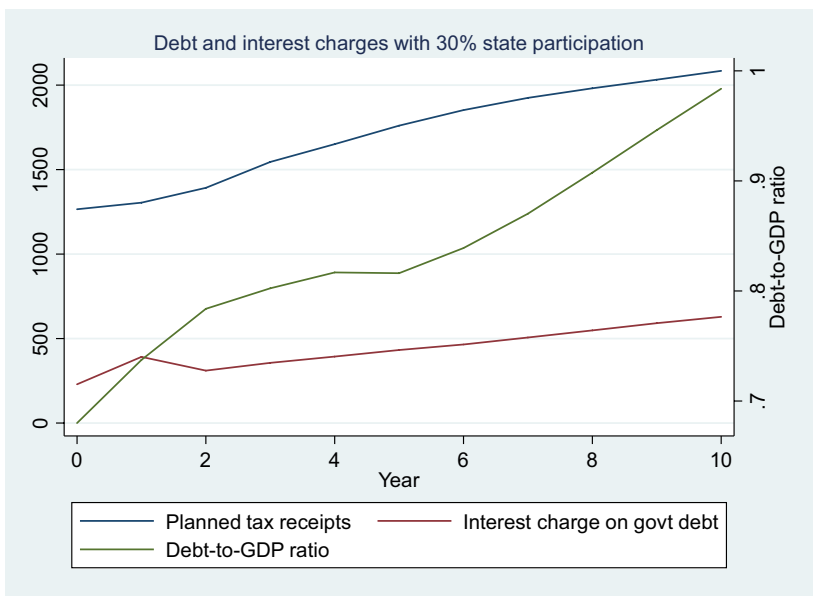

Fig. 5 Debt and interest charges at 30\% state participation (upper bound multiplier)

reduce the government debt-to-GDP ratio over time, sufficiently large primary surpluses have to be generated over an extended period. At the start of the Covid-19 pandemic, with an estimated GDP of ZAR 5058.4 billion and a tax revenue of 1539 billion, South Africa's primary balance was approximately $-0.04 \%$ of GDP and was projected to stabilise above zero as the country targeted to reduce the budget deficit to $5.7 \%$ of GDP in 2012/2023 fiscal year (Table 6).

In the current environment, the extent to which high debt ratios induce governments to adjust primary balances is an important question. The empirical evidence suggests that, ceteris paribus, governments tend to improve primary balances in response to rising debt-to-GDP ratios (ECB 2011). This can be done using the fiscal 


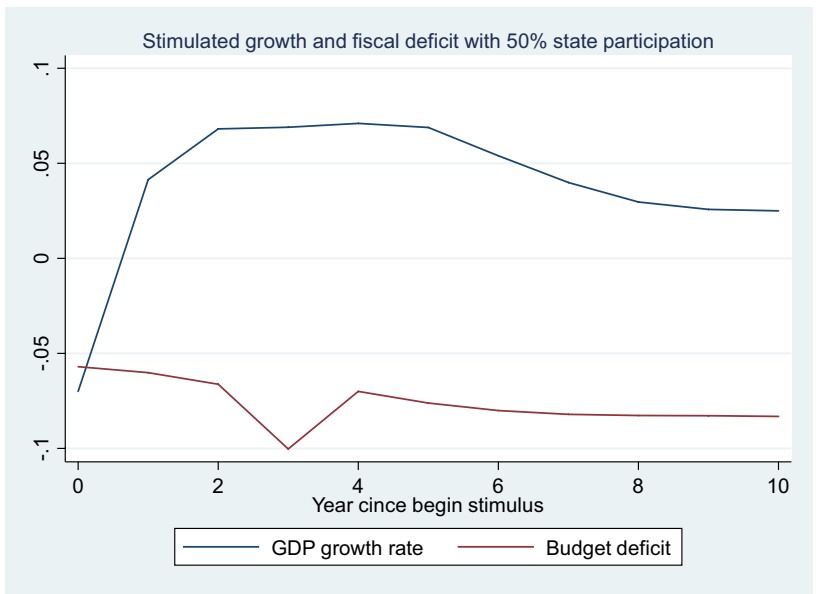

Fig. 6 Growth rate if 50\% state participation (lower bound multiplier)

rule proposed by Plödt and Reicher (2014), which suggests that the primary balance be automatically adjusted to the output gap and to the public debt. The application of such a rule, which encourages budgetary planning to run large primary surpluses, would result in a strong reduction in debt levels over time.

An overly optimistic scenario is when the government can partner with private investors at $50 \%$ participation in the infrastructure stimulus without crowding out private investment. This presupposes that the government agrees to match every rand of investment made by the private sector actors to reach the total package of ZAR 2.3 trillion over 10 years. This would cost the government ZAR 115 billion additional investment each year, above the planned expenditures. Assuming the government has the capacity to borrow the required funds without driving up the interest rate, the resulting investments would generate high growth rates. ${ }^{17}$ In this second scenario, the stimulus effects would push the growth rate above $6 \%$ in the second year even for the lower bound value of the multiplier. It would reach a peak value of $7.1 \%$ in the fourth year before gradually reverting to lower values (Fig. 6). In terms of growth stimulation, this scenario is very similar to that described by the upper bound value of the multiplier with $30 \%$ state participation in the investment package, only marginally higher.

Such a stimulated growth rate, as it is temporary, would, however, be achieved at the cost of increasing the government debt to $100 \%$ of the GDP in year seven and close to $120 \%$ in year ten (Fig. 7). The government debt would be pushed even higher with concomitant increase in the cost of borrowing if we consider the uncertainty about the costs of Covid-19. However, if the funds are invested in the types of public capital stock that support an upwards shift the production

\footnotetext{
17 The multipliers can become small or even negative if fiscal sustainability is in question, economic agents are forward looking, or monetary policy is not accommodative (Ramey 2020).
} 


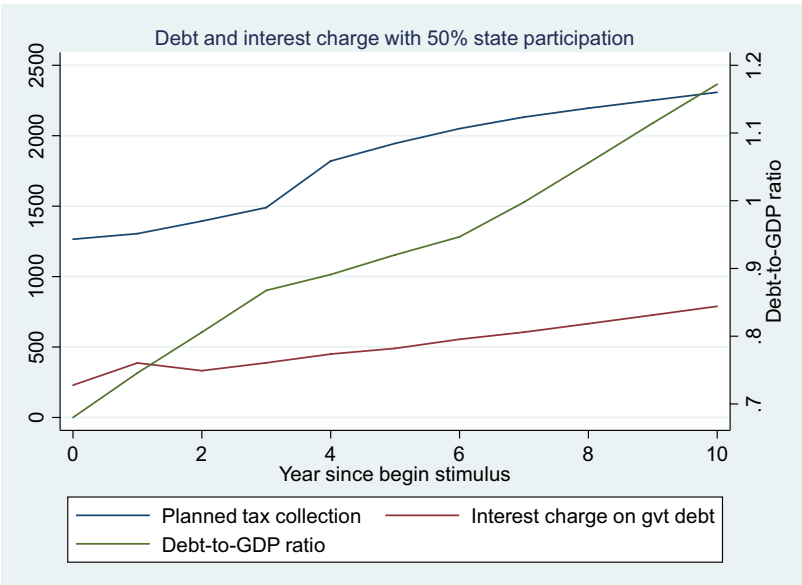

Fig. 7 Debt trajectory if 50\% state participation (lower bound multiplier)

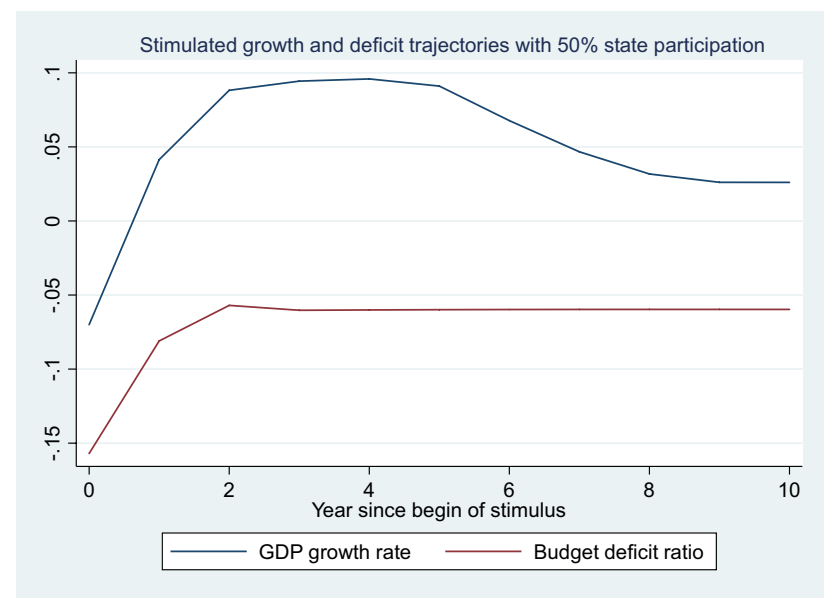

Fig. 8 Stimulated growth and deficit if 50\% state participation (upper bound multiplier)

function, then the growth momentum of the stimulus period can open the possibility of a more permanent shift in the growth trajectory through improved efficiency and economies of scale (Gallen and Winston 2019; Ramey 2020). Permanency of associated growth, however, requires that the infrastructure investment contribute to knowledge accumulation, which eventually leads to innovation and technological change.

The additional growth advantages can reduce the pressure of the growing debtto-GDP ratio and provide the state with more means to repay the borrowed funds in the future, if the monetary policy committee provides the necessary support by keeping the interest rate in check. 


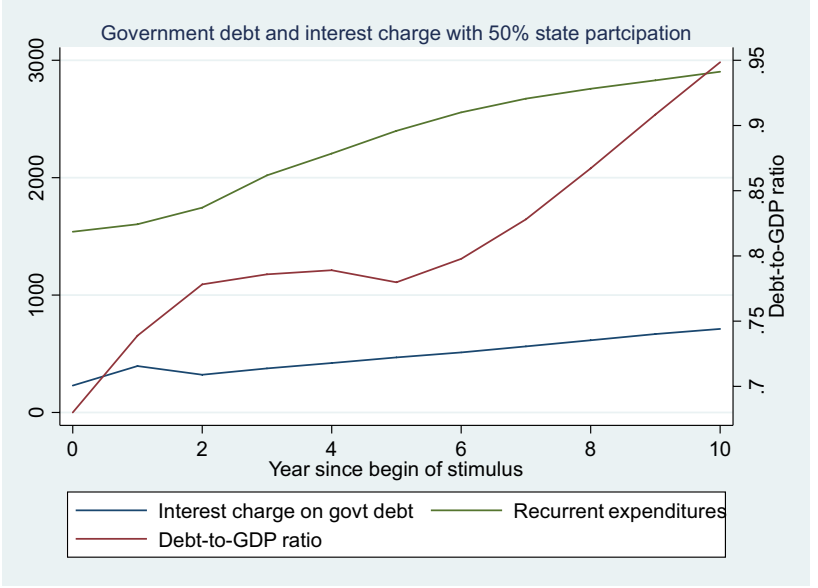

Fig. 9 Government debt if 50\% state participation (upper bound multiplier)

The trajectories described by the upper bound values of the multiplier in this scenario produces unlikely higher growth rates. The output growth generated by a yearly investment of ZAR 115 billion would peak to 9.5 in the fourth year of the stimulus and gradually revert to their lower trajectory and reach $2.6 \%$ in the ninth year (Fig. 8). This scenario would considerably increase the level of government debt, but the increased output during the years of high growth would keep the debt-to-GDP ratio from exploding. Assuming the government keeps the same tax collection rate, while moderating recurrent expenditures with respect to the GDP, the deficit can be maintained below the level of $6 \%$. Because of the corresponding higher GDP value, the debt-to-GDP ratio would increase less rapidly than in previous scenarios, would remain below $95 \%$ until year 10 o the stimulus period (Fig. 9). The ability of the government to collect taxes on the larger output would generate more revenues to finance recurrent expenditures and provisions for debt repayment.

This last scenario is, however, unlikely to unfold without triggering distorting factors, considering the speed with which it would increase the debt levels and the rapid adaptation that would be required to produce higher levels of output within the existing production capacity. Without access to concessional longterm loans, commitment to this additional debt burden would put upward pressure on the government bond yield and therefore reduce the multiplier effect. Moreover, with no capacity expansion in the short run, the corresponding growth rates would only be achieved by using more efficient production techniques and committing the required additional labour input in such a short time span. While the estimated multiplier can help us predict what is theoretically possible, predicting the path to the necessary adaptation is a more complex endeavour that is subject to the variation of multiple unpredictable factors. 


\section{Sensitivity Analysis}

Our analytical template is a flexible tool enabling to construct multiple "what-if scenarios" by changing any of more key assumptions. By smaller estimated output gaps, the gradual dissipation of the multiplier over the assumed five-year period can be modified to adapt to the level of output gap. The applied fiscal trajectory is based on the existing tax collection rate as presented on the National Treasury's 2020 Budget Review (National Treasury 2020b). In the second scenario, whereby the government takes a 50\% stake in the infrastructure expansion investments, if the government unexpectedly increase the tax rate from 26.3 to $30 \%$ in the fourth year of the stimulation, for example, it would be able to reduce the deficit to below $3 \%$ and keep the growth of the debt ratio to below $92 \%$ of the GDP in year 10 of the stimulus.

Varying the estimated value of the multiplier between its lower and upper bounds yields stable growth trajectories that lie between the shown extrema. Moreover, because of the assumed cumulative nature of the stimulus over the first five years of the investment period, variations in the estimated value of the multiplier behave almost similarly to variations in the size of the stimulus investment. An interest rate hike causes the interest charge to swell, which narrows the country's fiscal space and makes it costlier to borrow additional funds. This results in a reduction of both the multiplier and the amount of available funds for the stimulus.

\section{Implication for Employment and Income Inequality}

\section{Output Elasticity of Employment}

Because aggregate demand stimulation rests on the stickiness of prices and wages in the short term, fiscal multiplier effects are temporary by their dynamics. Consequently, fiscal stimulation is not an effective tool for long-term employment creation. ${ }^{18}$ For South Africa, existing elasticity estimates show a low responsiveness of employment growth to changes in GDP, which implies that employment gains from any potential recovery in output expansion are likely to be quite modest.

If output expands as a result of the fiscal stimulation, we can estimate its employment effects by relying on the employment elasticity of output. Employment multipliers represent estimates of the number of effective jobs created per million invested in the government stimulus. They can vary significantly in function of the type of infrastructure in which the stimulus is invested. For a sample of 27 advanced economies and 14 emerging markets covering the period 1999-2017 IMF (2020) estimated job intensity ranging from about two jobs per USD1 million invested in schools and hospitals to three jobs in electricity) in advanced economies, and from five jobs in roads to eight jobs in water and sanitation investment in emerging market

\footnotetext{
18 In fact, Ramey (2020)'s review of empirical literature finds more papers reporting negative effects than those reporting positive effects of infrastructure investments on employment.
} 
economies. Job intensity of public investment is estimated to be negatively correlated to each country's income level, because poorer countries have lower wages but also tend to use more labour-intensive technologies.

From a large sample of countries covering developed and emerging economies, empirical estimation by IMF staff indicates that in periods of uncertainty, employment increases by between 0.9 and $1.5 \%$ over two years in response to a shock of $1 \%$ of GDP to public investment (IMF 2020). For Spain, Alloza and Sanz (2020) estimated the employment multiplier to be 5.7 jobs created for every million EUR invested in the stimulus of municipalities during the 2008 crisis. For South Africa, Bhorat et al. (2014) estimated employment elasticity to be $0.69 \%$ increase in employment for $1 \%$ increase in GDP over the period 1997-2012. ${ }^{19}$ We use this elasticity to estimate the employment creation resulting from the stimulus growth. The Quarterly Employment Statistics reported a total employment of 10.23 million for the first quarter of 2020, i.e. before the estimated 3 million job losses as a result of the Covid-19 restriction measures. The recent National Income Dynamics Study (NIDS) report estimated that by October 2020, the economy had recovered 2.1 million of the jobs lost during the early months of the lockdown (Business Tech 2021). Using this estimated value of employment elasticity of output and assuming the labour market to adjust quickly and hire new workers to produce additional stimulus output, the cumulative expansion generated by the stimulated growth scenario with $30 \%$ state participation would result in a total of about 1.67 million new jobs creation over the first 5 years of the stimulus, of which 1.18 million would be attributable to the fiscal stimulation, the rest being generated by regular upward trend. This is far from enough to restore the 3 million job losses due to Covid. Growth trajectory involving 50\% state participation would generate 2.23 million jobs, 1.7 million of which can be attributed to the stimulus. Over the 10-year period of sustained investment in infrastructure (50\% state participation), 5.9 million new jobs could be created, with 4.9 million of them attributable to the stimulus. The stimulated employment restoration path is only possible if the inflationary pressures of output expansion are kept in check without making recourse to raising the interest rate. Temporary output expansion due to aggregate demand stimulation can, however, contribute to creating the conditions for permanent effects if the stimulus funds are invested in public capital stocks that increase future productivity (Fedderke and Bogetic 2009; Gallen and Winston 2019).

\section{The Burden of Skewed Income Distribution}

The highly skewed income and wealth distribution in South Africa impose undue limits to what a fiscal stimulus can achieve because of the credit constraint that prevents the low-income segment of the population to participate in the expansion

\footnotetext{
19 In a recent study, Schröder and Storm (2020) estimated the South African employment multiplier at 6.9 direct and indirect jobs created for each ZAR 1 million in additional stimulus spending (using 2018 input-output data).
} 
of aggregate demand. ${ }^{20}$ For the case of South Africa, the skewed income distribution has not only led to the highest levels of inequality in the world, but also to an economic stagnation characterised as a middle-income growth trap (Bhorat et al. 2014; Luiz 2016; Donner and Schneider 2016; Albuquerque 2019). The literature on wage-led growth provides insights into the additional opportunity for aggregate demand stimulate by shifting more income to wage earners and low-income households because of their higher marginal propensity to consume (Bhaduri and Marglin 1990; Bhaduri 2008; Lavoie and Stockhammer 2013). In fact, an income shift towards the lower quintiles of the income distribution stimulated the aggregate demand in the same way as a fiscal stimulus (Palley 2017; Lavoie and Stockhammer 2013). Given the stagnation that the country has been entangled in since the end of the Great Recession, the stimulation of aggregate demand is unlikely to produce significantly higher growth in the absence of encompassing structural reforms that address not only the production but also the redistribution of the national income between labour and capital (Bhaduri and Marglin 1990; Bhaduri 2008; Palley 2017).

\section{Concluding Remarks}

In this paper, we applied macroeconomic policy analysis tools to develop un understanding of the possible repercussions of South Africa's fiscal response to Covid-19 on growth performance but also on income distribution. We have followed a simplified yet reliable method to estimate fiscal multipliers for South Africa and used a flexible template to analyse how different scenarios of fiscal stimulation may affect growth trajectories in the wake of the health crisis. Despite limitations in the availability of reliable data, this simplified framework made it possible to build an evaluation scheme that sheds light on how possible stimulus scenario would affect the output growth trajectory as well as the corresponding evolution in the sustainability of government debt. Using the specific employment elasticity of output, we estimated the potential job creation associated with the sustained stimulus growth. Given the values of the estimated multipliers, we estimated that the proposed ZAR 2.3 trillion infrastructure package would contribute to restoring only a fraction of the 3 million jobs lost during the health crisis in the first five years of its inception, but would lead to a substantial increase in employment over 10 years.

The potential for the infrastructure package to generate additional growth and related employment in South Africa is dependent on sustained investment over several years to take advantage of the cumulative effects before the price adjustments dissipate the multiplier effects. Such a growth also depends on accommodating monetary policy to keep the interest rate from rising. Finally, the effectiveness of the state participation in the required investment is equally conditional on the quality of public administration of related funds as well the capacity to refrain from

\footnotetext{
20 A survey conducted in 2017 by Statistics South Africa showed that 20 percent of South African households were affected by hunger and food insecurity. That represents 6.8 million South Africans (1.7 million households) who were still experiencing hunger (StatSA 2019).
} 
distortionary taxes before the desired growth has been achieved. Given the narrow fiscal space that constrains the South African government's ability to raise the necessary funds on its own, partnering with private sector actors will require building long-term coalitions involving intertemporal bargaining between short-run costs and long-term advantages of an enhanced growth trajectory. As argued by Krugman (2009), an insufficient stimulus package can have unintended negative implications on the speed of recovery instead of fostering it.

The prospect of breaking out of stagnation must primarily rely on building domestic capabilities to absorb and internalise foreign technologies on large scale and develop autonomous innovation capabilities (Kruss 2021). This requires South Africa to determine the strategic growth areas in which it can build a dynamic comparative advantage based on its current strengths. The success of long-term capability building hinges in turn on whether the country can forge a social pact to facilitate the necessary intertemporal bargains to invest in upgrading-related development projects (Doner and Scheider 2016). It also requires a more judicious alignment between industrial and labour market policies in a way that gives priority to inclusiveness and sustainability. In the wake of the Covid-19 health crisis, South Africa (as the most unequal economy on the world experiencing stagnation) could take advantage of growth potential offered by shifts towards more equitable income redistribution as it seeks to expand capacity utilisation and employment opportunities.

The analysis presented in this study has several limitations requiring in interpretation of the results within the specified conditions: first, the estimation of the fiscal multiplier with the bucket method relies on general assessment of the prevailing conditions for assigning scores, without knowing which factor have more weight than other for the ultimate working of the fiscal multipliers. While the general quality of administration is assessed as one of the 6 scoring factors, it can be a limiting factor in extreme cases involving large widespread tendering distortions as were observed in the allocation of Covid-related contracting in South Africa.

The design of the growth scenario forecast templates also relies on assumptions made about the parameters that characterise the relationships between economic variables, while those relationships may change unpredictably over time. Nonetheless, its flexibility in the adaptation to changes in those parameters makes it compares favourably with competing methods, since the most sophisticated ones are equally reliant on assumptions.

Acknowledgements This study was conducted when Alexis Habiyaremye was with the Inclusive Economic Development division of the Human Science Research Council. We wish to thank Silas Mvulirwenande, Peter Jacobs, Yasser Buchana, Victor Habiyaremye, Manusha Pillai and Chijioke Nwosu for their insightful comments on the first draft of this paper. We also want to express our high appreciation for the anonymous reviewer, whose pertinent comments and diligent recommendations helped us increase the clarity of the arguments presented here. All remaining errors and omissions are the responsibility of the authors.

\section{Declarations}

Conflict of interest Authors declare that there is no conflict of interest involved in this study. 


\section{References}

Abiad, A., D. Furceri and P. Topalova. 2015. The macroeconomic effects of public investment: Evidence from advanced economies. IMF Working Paper WP/15/95, May 2015.

Ahmad, S. 2020. How COVID-19 exposes the defects in South Africa's digital economy. https://resea rchictafrica.net/2020/03/26/how-covid-19-exposes-the-defects-in-south-africas-digital-economy/.

Akanbi, O.A. 2013. Macroeconomic effects of fiscal policy changes: A case of South Africa. Economic Modelling 35: 771-785.

Albuquerque, E. 2019. Brazil and the middle-income trap: Its historical roots. Seoul Journal of Economics 32 (1): 23-62.

Alloza, M., and C. Sanz. 2020. Jobs multipliers: Evidence from a large fiscal stimulus in Spain. The Scandinavian Journal of Economics. https://doi.org/10.1111/sjoe.12428.

Arndt, C., R. Davies, S. Gabriel, L. Harris, K. Makrelov, B. Modise, and L. Anderson. 2020. Impact of Covid-19 on the South African economy. Southern Africa-Towards Inclusive Economic Development Working Paper 111.

Aschauer, D.A. 1989. Is public expenditure productive? Journal of Monetary Economics 23 (2): 177-200.

Auerbach, A.J., and Y. Gorodnichenko. 2012. Measuring the output responses to fiscal policy. American Economic Journal: Economic Policy 4 (2): 1-27.

Barro, R.J. 1974. Are government bonds net wealth? Journal of Political Economy 82 (6): 1095-1117.

Batini, N., G. Callegari, and G. Melina. 2012. Successful Austerity in the United States, Europe and Japan. IMF Working Paper 12/190. Washington: International Monetary Fund.

Batini, N., L. Eyraud, and A. Weber. 2014a. A simple method to compute fiscal multipliers. IMF Working Paper 14/93. Washington: International Monetary Fund.

Batini, N., L. Eyraud, L. Forni, and A. Weber. 2014b. Fiscal multipliers: Size, determinants, and use in macroeconomic projections. International Monetary Fund: IMF Technical Notes and Manuals. Wshington DC.

Baum, A., M. Poplawski-Ribeiro, and A. Weber. 2012. Fiscal Multipliers and the State of the Economy. IMF Working Paper 12/286. Washington: International Monetary Fund.

Baxter, M., and R. King. 1993. Fiscal Policy in General Equilibrium. American Economic Review 83 (3): $315-334$.

Bhaduri, A. 2008. On the dynamics of profit-led and wage-led growth. Cambridge Journal of Economics 32: $147-160$.

Bhaduri, A., and S. Marglin. 1990. Unemployment and the real wage: The economic basis for contesting political ideologies. Cambridge Journal of Economics 14: 375-393.

Bhorat, H., A. Cassim, and A. Hirsch. 2014. Policy co-ordination and growth traps in a middle-income country setting: The case of South Africa. UNU-WIDER Working paper 2014/155.

Bi, R., M.H. Qu, and M.J. Roaf. 2013. Assessing the impact and phasing of multi-year fiscal adjustment: A general framework. IMF Working Paper 13/182. Washington DC: International Monetary Fund.

Blanchard, O., and R. Perotti. 2002. An empirical characterization of the dynamic effects of changes in government spending and taxes on output. Quarterly Journal of Economics 117 (4): 1329-1368.

Boussard, J., F. de Castro, and M. Salto. 2013. Fiscal multipliers and public debt dynamics in consolidations. Encuentro Economía Pública (1-36). Sevilla: Universidad de Sevilla.

Business Tech. 2019. South Africa has another massive problem - its roads, 12 June. https://businesstech. co.za/news/business/322939/south-africa-has-another-massive-problem-its-roads/.

Business Tech. 2021. South Africa recovered 2 million jobs lost during lockdown- but there's a catch, 17 February. https://businesstech.co.za/news/business/468714/south-africa-recovered-2-million-jobslost-during-lockdown-but-theres-a-catch/.

Calderón, C., and L. Servén. 2004. The effects of infrastructure development on growth and income distribution. Washington DC: The World Bank.

Christiano, L., M. Eichenbaum, and S. Rebelo. 2011. When is the government spending multiplier large? Journal of Political Economy 119 (1): 78-121.

CIA. 2020. World Factbook. South Africa Transportation infrastructure. https://www.cia.gov/the-worldfactbook/countries/south-africa/\#transportation.

Coenen, G., C.J. Erceg, C. Freedman, D. Furceri, et al. 2012. Effects of fiscal stimulus in structural models. American Economic Journal: Macroeconomics 4 (1): 22-68.

Devarajan, S., and D.S. Go. 1998. The simplest dynamic general-equilibrium model of an open economy. Journal of Policy Modeling 20: 677-714. 
Dolls, M., C. Fuest, and Peichl, A. 2012. Automatic stabilizers and economic crisis: US vs. Europe. Journal of Public Economics 96: 279-294.

Doner, R., and B. Schneider. 2016. The middle-income trap. World Politics 68 (04): 608-644.

ECB [European Central Bank]. 2011. Economic and monetary developments. ECB Monthly Bulletin: March 2011.

Eggertsson, G.B. 2011. What fiscal policy is effective at zero interest rates? NBER macroeconomics annual 2010, vol. 25. Cambridge, MA: National Bureau of Economic Research.

Engle, R., and C. Granger. 1987. Cointegration and error correction: Representation, estimation, and testing. Econometrica 55: 251-276.

Fedderke, J., and Z. Bogetic. 2009. Infrastructure and growth in South Africa: Direct and indirect productivity impacts of 19 infrastructure measures. World Development 37: 1522-1539.

Financial Mail. 2019. Financial report infrastructure, July 25.

Galí, J., J.D. Lopez-Salido, and J. Valles. 2007. Understanding the effects of government spending on consumption. Journal of the European Economic Association 5 (1): 227-270.

Gallen, T., and C. Winston. 2019. Transportation and its Effects on the U.S. Economy: A General Equilibrium Approach. Technical report, Purdue University.

Goodfriend, M., and R.G. King. 1997. The new neoclassical synthesis and the role of monetary policy. NBER Macroeconomics Annual 12: 231-283.

Gorodnichenko, Y., E.G. Mendoza, and L.L. Tesar. 2012. The finnish great depression: From Russia with love. American Economic Review 102: 1619-1644.

Gramlich, E.M. 1994. Infrastructure investment: A review essay. Journal of economic literature 32 (3): 1176-1196.

Hall, R. 2009. By how much does GDP rise if the government buys more output? Brookings Papers on Economic Activity 40 (2): 183-231.

Ilzetzki, E., E.G. Mendoza, and C.A. Vegh. 2013. How big (small?) Are fiscal multipliers? Journal of Monetary Economics 60: 239-254.

IMF. 2020. Public investment for the recovery. IMF Fiscal Monitor, October 2020.

Isa, M. 2019. Why is South Africa still waiting for cheaper data? Fin24, 13 August. https://www.news24. com/fin24/finweek/featured/why-is-south-africa-still-waiting-for-cheaper-data-20190813.

Jooste, C., G. Liu, and R. Naraidoo. 2013. Analysing the effects of fiscal policy shocks in the South African economy. Economic Modelling 32: 215-224.

Kemp, J.H., and H. Hollander. 2020. A medium-sized, open-economy, fiscal DSGE model of South Africa. UNU-WIDER Working paper 2020/92.

Krueger, A. 2020. The open secret to reopening the economy. Project Syndicate, 23 July.

Krugman, P. 2009. The return of depression economics and the crisis of 2008. New York: W.W. Norton.

Kruss, G. 2021 Catching up, falling behind: The need to build upgrading coalitions for innovation and inclusive development in South Africa. Forthcoming in Nova Economica.

Lavoie, M., and E. Stockhammer. 2013. Wage-led growth: Concept, theories and policies. In Wage-led growth: 13-39. Springer.

Luiz, J.M. 2016. The political economy of middle-income traps: Is South Africa in a long-run growth trap? The path to "bounded populism. South African Journal of Economics 84: 3-19.

Mabugu, R., V. Robichaud, H. Maisonnave, and M. Chitiga. 2013. Impact of fiscal policy in an intertemporal CGE model for South Africa. Economic Modelling 31: 775-782.

Makgetla, N. 2013. Financialisation in South Africa: A discussion document. Pretoria: Department of Economic Development, UNDP and UNDESA.

Makrelov, K., C. Arndt, R. Davies, and L. Harris. 2018a. Stock-and-flow-consistent macroeconomic model for South Africa. UNU-WIDER SA-TIED Working Paper No 2018/7.

Makrelov, K., C. Arndt, R.H. Davies, and L. Harris. 2018b. Fiscal multipliers in South Africa: The importance of financial sector dynamics. UNU-WIDER Working Paper No. 2018/6).

Mineshima, A., M. Poplawski-Ribeiro, and A. Weber. 2014. Fiscal multipliers. In Post-crisis fiscal policy, ed. C. Cottarelli, P. Gerson, and A. Senhadji. Cambridge: MIT Press.

Naidoo, P. 2020. Treasury to allocate last R45 billion of coronavirus relief package. IOL, July 8.

National Income Dynamic Study. 2020. Coronavirus rapid mobile survey. https://cramsurvey.org/.

National Planning Commission. n.d. Economic infrastructure. https://nationalplanningcommission.wordp ress.com/economic-infrastructure/.

National Treasury of the Republic of South Africa. 2020a. Measures for Covid 19. Pretoria.

National Treasury of the Republic of South Africa. 2020b. Budget Review 2020. February 26, Pretoria.

National Treasury of the Republic of South Africa. 2020c. supplementary budget 2020. Pretoria. 
Ntjatsane, M. 2017. Financing of infrastructure maintenance in South Africa. Master's thesis, Wits Business School. The University of the Witwatersrand.

Palley, T.I. 2017. Wage- vs. profit-led growth: The role of the distribution of wages in determining regime character. Cambridge Journal of Economics 41: 49-61.

Plödt, M., and C. Reicher. 2014. Primary balance and debt projections based on estimated fiscal reaction functions for euro area countries. Revue de l'OFCE 132: 111-134.

Ramey, V. 2020. The macroeconomic consequences of infrastructure investment. Paper prepared for November 15-16, 2019 NBER Conference on the "economics of infrastructure".

Reinhart, C., V. Reinhart, V. and K. Rogoff. 2012. Debt overhangs: Past and present, NBER Working Paper No18015.

Rotenberg, J., and M. Woodford. 1992. Oligopolistic pricing and the effects of aggregate demand on economic activity. Journal of Political Economy 100 (6): 1153-1297.

Schröder, E., and S. Storm. 2020. Fiscal policy in South Africa: Closed input-output income and employment multipliers. Institute for Economic Justice. Research Note No 1.

Sguazzin, A. 2020. South Africa outlines plan for \$133 billion building boom. Biz News, 24 June.

Sinai, A. 2009. Macroeconomic policy challenges and choices in a time of crises: Part II: Fiscal policy and policies for "recovery." Challenge 52: 53-93.

Smets, F., and R. Wouters. 2007. Shocks and frictions in US business cycles: A Bayesian DSGE approach. American Economic Review 97: 586-606.

Smit, S. 2020. Three million jobs lost and hunger surging amid Covid-19 crisis—survey. Mail \& Guardian, 15 July.

Spilimbergo, M., M. Schindler, and M. Symansky. 2009. Fiscal multipliers. Washington DC: International Monetary Fund.

StatSA. 2019. Towards measuring food security in South Africa: An examination of hunger and food inadequacy. Statistics South Africa Statistical Report 03-00-14.

StatSA. 2020. Quarterly Labour force survey (Q1 2020). Pretoria: Statistics South Africa.

Taylor, J.B. 1993. Discretion versus policy rules in practice. Carnegie-Rochester Conference Series on Public Policy 39: 195-214.

U.S. Congressional Budget Office (2016) The macroeconomic and budgetary effects of Federal Investment. Research Report, June.

Van Rensburg, J.A., and S.C. Krygsman. 2019. Funding for roads: Understanding the South African road funding framework. Journal of Transport and Supply Chain Management 13: 453.

Verick, S., and I. Islam. 2010. The great recession of 2008-2009: Causes, consequences and policy responses. ILO Employment Working Paper No 61. Geneva: International Labor Orgainization.

Yülek, M.A., K. Göksal, and M.H. Yağmur. 2018. Long-term effects of fiscal policy: Public infrastructure investment and sustained growth. In Industrial policy and sustainable growth. Sustainable development, ed. M. Yülek. Singapore: Springer.

Publisher's Note Springer Nature remains neutral with regard to jurisdictional claims in published maps and institutional affiliations. 